\title{
Evaluation of Actinide Biosorption by Microorganisms
}

Anne M. Happel

RECEIVED

OCT 211996

OSTI

June 1996

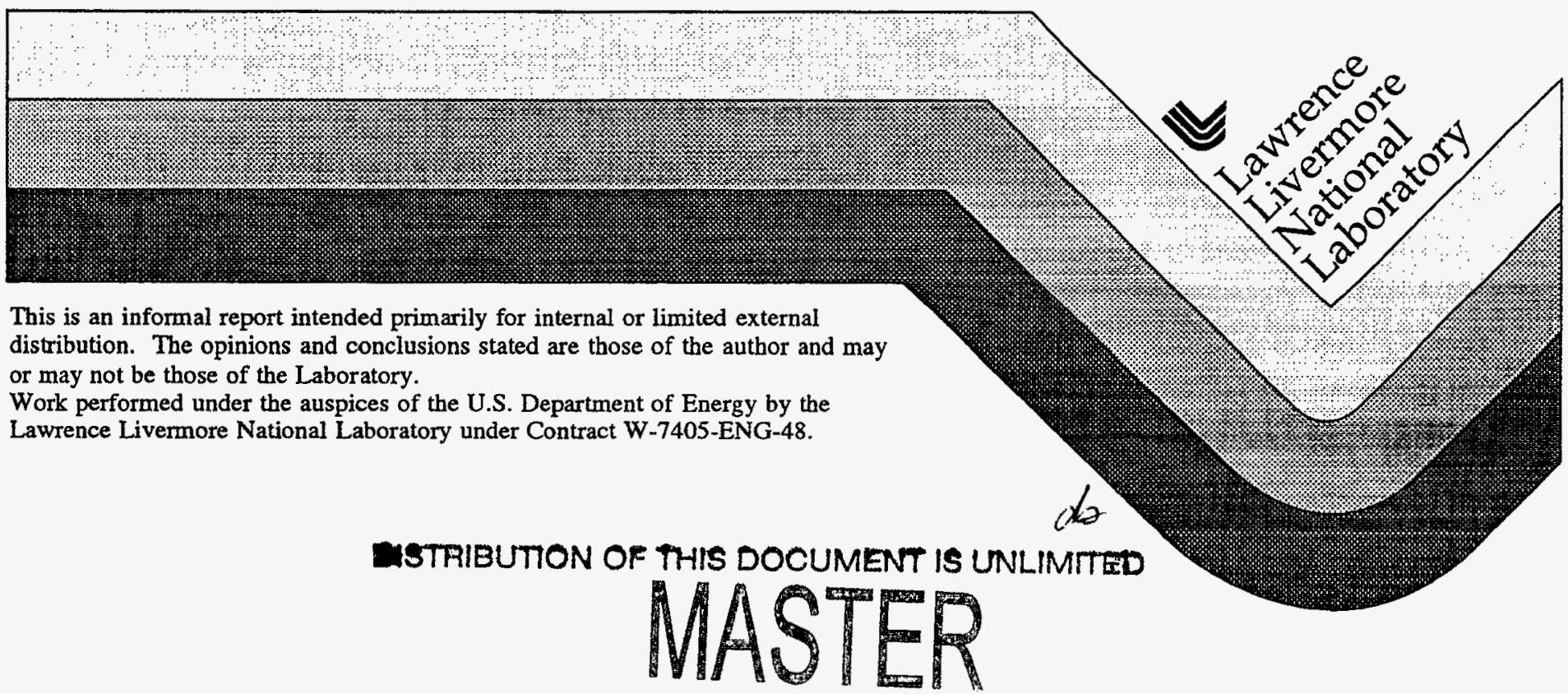




\section{DISCLAIMER}

This document was prepared as an account of work sponsored by an agency of the United States Government. Neither the United States Government nor the University of California nor any of their employees, makes any warranty, express or implied, or assumes any legal liability or responsibility for the accuracy, completeness, or usefulness of any information, apparatus, product, or process disclosed, or represents that its use would not infringe privately owned rights. Reference herein to any specific commercial product, process, or service by trade name, trademark, manufacturer, or otherwise, does not necessarily constitute or imply its endorsement, recommendation, or favoring by the United States Government or the University of California. The views and opinions of authors expressed herein do not necessarily state or reflect those of the United States Government or the University of California, and shall not be used for advertising or product endorsement purposes.

This report has been reproduced directly from the best available copy.

Available to DOE and DOE contractors from the

Office of Scientific and Technical Information

P.O. Box 62, Oak Ridge, TN 37831

Prices available from (615) 576-8401, FTS 626-8401

Available to the public from the

National Technical Information Service

U.S. Department of Commerce

5285 Port Royal Rd.

Springfield, VA 22161 
Evaluation of Actinide Biosorption by Microorganisms

$$
\text { Anne Happel }
$$

Glenn T. Seaborg Institute for Transactinium Science, Lawrence Livermore National Laboratory 


\section{DISCLAIMER}

Portions of this document may be illegible in electronic image products. Images are produced from the best available original document. 


\section{INTRODUCTION:}

Conventional methods for removing metals from aqueous solutions include chemical precipitation, chemical oxidation or reduction, ion exchange, reverse osmosis, electrochemical treatment and evaporation. The removal of radionuclides from aqueous waste streams has largely relied on ion exchange methods which can be prohibitively costly given increasingly stringent regulatory effluent limits. The use of microbial cells as biosorbants for heavy metals offers a potential alternative to existing methods for decontamination or recovery of heavy metals from a variety of industrial waste streams and contaminated ground waters. The toxicity and the extreme and variable conditions present in many radionuclide containing waste streams may preclude the use of living microorganisms and favor the use of non-living biomass for the removal of actinides from these waste streams. In the work presented here, we have examined the biosorption of uranium by non-living, non-metabolizing microbial biomass thus avoiding the problems associated with living systems.

We are investigating biosorption with the long term goal of developing microbial technologies for the remediation of actinides. Biosorption is essentially a passive process in which metal ions bind to a microbial cell surface. This cellular surface uptake of metals from solutions is usually a fast, $\mathrm{pH}$-dependent process.

Biosorption may include several types of non-active metal uptake by microbial biomass including: complexation, coordination, chelation, ion exchange, adsorption, and inorganic microprecipitation. An individual microbial biosorbent may use more than one metal binding mechanism for the bioaccumulation of a individual metallic species. Metallic cations may be attracted to negatively charged sites on the cell surface where a variety of anionic ligands of the cell wall or membrane components can participate in metal binding (i.e. phosphoryl, carboxyl, sulfhydryl, and hydroxyl groups of surface proteins, polysaccharides and carbohydrates) (Lundgren and Malouf 1983; Crist et al., 1988). Therefore, the chemical and structural interaction of the components of the cell surface should influence the capacity of different microorganisms to selectively bioaccumulate metals.

Previous workers have shown that heavy metals, particularly the uranyl ion, are bound preferentially to microbial biomass. This probably is a result of its large atomic weight and ionic radius (Tobin et al., 1984). We have investigated the biosorption of uranium by a number of microorganisms. We have examined biosorption of uranium under a variety of conditions. In several experiments we have manipulated the growth conditions of the microbial cells to determine whether this would result in physiological changes in the microorganisms that would influence uranium biosorption.

\section{MATERIALS and METHODS:}


Media and growth conditions. Microorganisms used in these studies are listed in Table 1. Microorganisms were cultured in rich complex medias under aerobic conditions to maximize the amount of biomass produced. For each microorganism, growth in these medias after inoculation was determined by measuring increases in optical density via Klet or spectrophotometric readings at $600 \mathrm{~nm}$. Typical growth curves of bacteria used in these experiments are presented in Figure 4.

Biomass was harvested from the bacterial cultures during two specific phases of growth: 1. the exponential growth phase, or 2. the stationary phase of growth. (Abbreviations for each stage of growth are as follows: $\mathrm{E}$ and $\mathrm{S}$, respectively.) Cells were harvested by centrifugation and washed two times with distilled deionized water $\left(\mathrm{ddH}_{2} \mathrm{O}\right)$ at $4^{\circ} \mathrm{C}$. The biomass was then lyophilized to dehydrate the biomass while preserving the cell structure. The freeze dried biomass was stored in screw-cap tubes in the presence of a drying agent at $4^{\circ} \mathrm{C}$. Prior to each experiment, the dried biomass was weighed then resuspended in $\mathrm{ddH}_{2} \mathrm{O}$ and allowed to rehydrate overnight at $4^{\circ} \mathrm{C}$. The rehydrated biomass was then washed two times and resuspended in $\mathrm{ddH}_{2} \mathrm{O}$ $\mathrm{pH} 3.4$ or 4.6 (due to addition of HCL) before incubating the biomass with the uranium solution.

All Bacillus species were grown in DSM at $37^{\circ} \mathrm{C}$; all Pseudomonas species were grown in $\mathrm{LB}$ at $27^{\circ} \mathrm{C}$; and all yeast strains were grown in YPD at $37^{\circ} \mathrm{C}$.

Metal uptake experiments. In the uranium uptake experiments, an aliquot of rehydrated cells $(0.25$ or $0.5 \mathrm{mg}$ dry weight) was resuspended with uranyl nitrate solution $(0.6,1.0$, or $1.2 \mathrm{ml}$ total volume) and mixed gently for 60 minutes at room temperature. Uranyl nitrate solutions were prepared at $\mathrm{pH}$ 3.7 and 4.6 at $2 \mathrm{mM}$. All experiments were conducted in sterile polypropylene tubes. Following the incubation, samples were centrifuged ( 3 minutes at $12,000 \mathrm{rpm}$ in an Eppendorf microfuge) to pellet the biomass. Aliquots of the supernatant ( 30 to $100 \mathrm{ul}$ ) were used for determination of the uranium concentration remaining in solution. Experiments were conducted at $\mathrm{pH} 4.6$ and 3.7 with uranium concentrations ranging from 0.08 to $1.1 \mathrm{mM}$. All experimental samples were paired with a no biomass control. Controls without biomass were sampled before and after centrifugation to investigate uranium losses. Losses of uranium measured in these controls were minimal; maximum losses observed were less than $5 \%$.

Measurement of uranium. Dissolved uranium was measured by spectrophotometry using Arsenazo III (Motojima et al. 1969). In this work cell-bound uranium was calculated by difference between the measured the amount of uranium remaining in solution and the initial uranium concentration. 


\section{RESULTS and DISCUSSION:}

Comparison of Uranium Bioaccumulation by Various Microorganisms: Initial tests were performed to measure the accumulation of uranium by fourteen microorganisms listed in Table 1 . The effect of uranium concentration on uranium biosorption by these microbial strains was tested for at least three uranium concentrations ranging from 0.125 to $1.1 \mathrm{mM}(\mathrm{pH}$ 4.6; cell density of 1.0 gram dry weight of biomass per liter; 60 minutes incubation). Under these conditions, the amount of uranium absorbed by the microbial cells differs markedly in different species and strains of these microorganisms (Figure 1). Seven of the fourteen microbial strains showed the ability to biosorb significant concentrations of uranium, $80-115 \mathrm{mg}$ of uranium per gram dry weight of biomass, in one hour at uranium concentrations greater than $0.5 \mathrm{mM}$. In these experiments all microbial strains bound more uranium when challenged with solutions containing increasing concentrations of uranium, as is expected for an adsorptive process.

Uranium Uptake for Gram-Positive Versus Gram-Negative Microorganisms: Microbial strains tested for biosorption of uranium included: six grampositive bacteria, six gram-negative bacteria and two yeast (Table 1). Of the seven microorganisms showing the highest uptake, four were gram-positive (Bacillus subtilis PY79, Bacillus subtilis P168, Bacillus cereus A1, and Streptomyces longwoodensis, Figures $1 \mathrm{~A}$ and $1 \mathrm{~B}$ ) and three were gramnegative (Pseudomonas fluorescens Pf0-1, Pseudomonas fluorescens Pf1-1, and Pseudomonas putida Pp1-1, Figures 1C and 1D). While gram-positive and gram-negative microorganisms have very dissimilar cell structures, results from these experiments show no correlation between uranium biosorption and gram-positive or gram-negative cell classifications. Review of uranium biosorption results obtained by Nakajima and Sakaguchi (1986) also further substantiate this conclusion. These authors tested 83 microorganisms for uranium biosorption under a single set of uptake conditions $(0.04 \mathrm{mM} \mathrm{U}, \mathrm{pH} 4.6,0.05 \mathrm{~g}$ dry weight biomass/ $\mathrm{L}, 1$ hour shaking at $30^{\circ} \mathrm{C}$ ). Among the 16 strains that showing the highest uptake for uranium, both gram-negative and gram-positive strains were present.

Additionally, experiments examining biosorption of copper by three bacterial strains (Mullen et al., 1989) also indicated that uptake of $\mathrm{Cu}^{2+}$ by whole cell biomass did was not determined by gram-positive and gram-negative classifications.

Experiments examining the biosorption of metals to isolated cell walls and cell envelopes have reported that gram-positive cell walls have a high affinity for metal ions including the uranyl ion (Beveridge and Fyfe, 1985; Beveridge 1989; Urrutia Mera et al., 1992). In contrast to the whole cell results, the results from one $\mathrm{Cu}^{2+}$ biosorption study (Beveridge and Fyfe, 1985) have been interpreted as indicating that gram-positive cell walls have bind higher amounts of metals than gram-negative envelopes (Mullen et al., 1989). In 
this study, isolated $B$. Subtilis and $B$. licheniformis gram-positive cell walls bound 28 to 33 times more $\mathrm{Cu}^{2+}$ than gram-negative $E$. coli envelopes (Beveridge and Fyfe 1985). However, the limited number of microorganisms used in the $\mathrm{Cu}^{2+}$ sorption experiments precludes any generalizations concerning the metal binding properties of gram-positive cell walls versus gram-negative envelopes.

\section{Uranium Biosorption for Yeast Strains:}

Results from experiments examining the effect of uranium concentration on uranium biosorption by yeast strains (Figure 1E) demonstrated poor uranium uptake for Saccharomyces cerevisiae FY2 and Schizosaccharomyces pombe FWP9. These results agree with the results of Nakajima and Sakaguchi (1986). Uranium uptake for 15 yeast strains among 83 different species of microorganisms tested was weaker than species of actinomycetes, fungi and bacteria.

These results appear to contradict the results of Strandberg et al., (1981). They reported that a Saccharomyces cerevisiae strain could biosorb up to 100$150 \mathrm{mg}$ uranium per gram cell dry weight within 2 to 4 hours. Uptake of 11 $\mathrm{mg}$ uranium per gram cell dry weight by Saccharomyces cerevisiae was measured by Nakajima and Sakaguchi (1986) and our results (Figure 1) show approximately $20-40 \mathrm{mg}$ uranium per gram cell dry weight is biosorbed by Saccharomyces cerevisiae within 1 hour. Since the $\mathrm{pH}$ conditions were similar between experiments, 4.5-4.6, the determining factor in these experiments is most likely the concentration of uranium in the initial challenge solution. Nakajima and Sakaguchi (1986) and tests presented in this paper use low uranium concentrations, $0.04 \mathrm{mM}$ and $0.1-0.8 \mathrm{mM}$ respectively, in the initial challenge solution, whereas the Strandberg et al experiments utilized higher concentrations of uranium in the challenge solution, $4.2 \mathrm{mM}$. As seen in our experiments (Figure 1A-E) and many other studies increasing the concentration of uranium in the challenge solution results in higher uptake of uranium. Thus, a large increase in the uranium concentration would be expected to increase amounts of uranium bound by the microbial cells. Another contributing factor may have been the speciation of uranium in these experiments. Uranium hydrolysis modeling results for a $2 \mathrm{mM}$ solution are shown in Figure 2. At a pH of 4.6 a majority of the uranium is predicted to be present as $\mathrm{UO}_{2}{ }^{2+}$; formation of $\mathrm{UO}_{2}(\mathrm{OH})_{2}$ becomes favored above this $\mathrm{pH}$. However, increases in uranium concentration will favor formation of $\mathrm{UO}_{2}(\mathrm{OH})_{2}$. Since $\mathrm{UO}_{2}(\mathrm{OH})_{2}$ will form precipitable polymers, formation of this species may have exaggerated the apparent biosorption of uranium observed in these experiments.

Uranium Uptake Characteristics for Microbial Strains of a Given Species: In our initial tests (Figure 1), several strains of the same microbial genus and species were tested for uranium biosorption to determine whether strains of the same species would have similar abilities to biosorb uranium. 
Interestingly, strains of the same genus and species often exhibit quite different abilities to biosorb uranium (Figure 1A-E). For example, uranium uptake by four Bacillus cereus strains results in a broad range of biosorption abilities (Figure 1B). Under the conditions used in these experiments, $B$. cereus $A 1$ biosorbs much higher concentrations of uranium than the other three $B$. cereus strains tested; uranium uptake was about two-fold greater, approximately 90 versus $35-55 \mathrm{mg}$ uranium biosorbed per gram dry cell weight with an initial uranium concentration of $0.5 \mathrm{mM}$. The three Pseudomonas fluorescens strains tested also showed quite different uranium biosorption characteristics. Again maximum uptake of uranium varied almost two-fold; $P$. fluorescens $P f 0-1$ biosorbed approximately 95 versus 55 mg uranium per gram dry cell weight for $P$. fluorescens $P f 2-1$ (challenge uranium concentration of $0.5 \mathrm{mM}$ ).

In contrast to these results, the Bacillus subtilis strains, the Pseudomonas putida strains and the yeast strains showed similar uranium sorption characteristics (Figure 1A, D, and E). Nearly identical biosorption results are expected for the B. subtilis strains, since the strains tested, PY79 and P168, are genetically defined strains with similar genotypes. Therefore, cells from these strains would produce nearly identical proteins and carbohydrates on their cell surfaces that may be responsible for biosorption of uranium. The Pseudomonas putida strains are environmental isolates (Compeau et al., 1988) and no information is available to indicate whether these strains are in fact closely related. The yeast strains in general appear to biosorb only low amounts of uranium (discussed above). Therefore, it is not surprising that both yeast strains exhibited similar limited biosorption characteristics. These results clearly show that the classification by microbial species can not be used to predict uranium biosorption. However strains that are closely genetically related are expected to exhibit similar uranium biosorption abilities.

Investigation of Culture Growth Conditions Effect on Uranium Biosorption: Both microbial culture conditions and the growth phase of the biomass influence the physiological structure and composition of the microbial cell. Several previous studies have demonstrated that different growth conditions can effect the ability of several microorganisms to biosorb uranium. The age of the microbial culture produced a significant effect on uranium uptake for $R$. arrhizus (Treen-Sears et. al, 1984). Likewise, $S$. cerevisae cultures grown on a synthetic medium had a 2.5 fold faster rate of uranium uptake than cultures grown on a rich organic medium (Strandberg et al., 1981). Additionally, growth on different culture media was also shown to affect thorium uptake after a detergent treatment by five of six microorganisms tested (Gadd and White, 1988). Uptake of strontium by Micrococcus luteus was shown to be sensitive to the culture temperature; cells cultured at $30^{\circ} \mathrm{C}$ bound more strontium than cells grown at 25 or $35^{\circ} \mathrm{C}$ (Faison et al., 1990). Culture age also influenced the uptake of copper and cadmium by Zoogloea ramigera (Norberg, 1984); maximum metal uptake occurred with six to eight day old cultures. 
We have further investigated biomass growth conditions by testing uranium biosorption of cells harvested during periods of exponential growth or early stationary phase (Figure 4). During exponential growth phase rapid cell division occurs. When growth conditions become limited, cells tend to cease dividing and the physiology of the cells is often dramatically affected. We tested uranium biosorption of five bacterial strains whose biomass was harvested during exponential (E) or stationary phase (S) of growth (Figure 4). For at least one of the five bacterial strains, P. putida Pp1-1 the specific phase of growth had dramatic (approximately two-fold) effects on uranium biosorption (Figure $5 \mathrm{E}$ ). In contrast, the growth phase had no effect on uranium uptake by B. subtilis PY79 (Figure 5A). Therefore, this indicates that the cellular components responsible for uranium uptake in B. subtilis PY79 are present during exponential and stationary phases of growth. The remaining three strains, $B$. cereus $A 1, B$. cereus $S 1$, and $P$. fluorescens $P f O-1$ (Figures 5B, 5C and 5D) showed a minor, yet consistent, difference in uranium uptake by cells harvested during exponential versus stationary phases of growth. For two of these strains uranium uptake was greater for the exponential cells (Figure 5B and $5 \mathrm{C}$ ), while one strain showed the greatest uranium uptake for stationary cells (Figure 5D). Thus, in order to accurately compare uranium biosorption by a specific microbial strain in separate studies, growth conditions should be identical (i.e. culture medium and temperature) and cells must be harvested in same phase of growth.

\section{Variation of Cell Density:}

The concentration of cells in the growth phase experiments described above was varied to test whether uranium uptake was consistent at different cell densities. Exponential and stationary phase cells from each strain were tested for uranium uptake at cell densities of 0.25 and $0.5 \mathrm{mg}$ per liter from solutions containing approximately $0.24 \mathrm{mM}$ uranium. Changes in cell density appear to result in minor differences in uranium uptake (Figures 5A-5E). While three strains increased uranium uptake at the higher cell density (Figure 5B, $5 \mathrm{C}$, and $5 \mathrm{E}$ ), two strains showed a slight decrease in uranium sorption with an increase in cell density (Figure 5A and 5D).

Two cell densities $(0.25 \mathrm{~g} / \mathrm{L}$ and $0.5 \mathrm{~g} / \mathrm{L})$ of Bacillus subtilis PY79 and Pseudomonas fluorescens PfO-1 were tested further with increasing concentrations of uranium (Figure 3A-F). Again, these strains showed a slight decrease in uranium sorption with an increase in cell density (Figure 3E and F). This effect may be more exaggerated for B. subtlis PY79. Higher cell densities may result in greater flocculation of cells and therefore a reduction in cell surface area for the biosorption of uranium.

\section{Uranium Biosorption by B. subtilis Spores:}

Spores of $B$. subtilis were purified and tested for uranium biosorption. In experiments described above, $B$. subtilis vegetative cells demonstrated a high capacity for uranium biosorption independent of the growth phase of the harvested cells. Interestingly, B. subtilis spores showed an extremely poor 
uranium biosorption capacity; spores bound between 11 and $18 \mathrm{mg}$ uranium per gram dry weight of spores. Therefore, the cellular components responsible for uranium uptake appear absent from the spore structure.

To further investigate the cellular determinants required for uranium biosorption, isogenic strains of $B$. subtilis spores that carry separate mutations affecting the spore cell surface were tested (Table 2). Each of these mutant strains produces spores with defects in specific proteins or structure of the spore coat. While $B$. subtilis spores demonstrate only very limited uptake of uranium, this limited binding was not significantly affected by a majority of the defects in the spore coats exhibited in the mutant strains. Only the gerE36 mutant showed a potentially significant (approximately two-fold) greater binding than the wild type spores. Therefore, these results indicate that the limited uranium binding exhibited by Bacillus subtilis spores is generic- not specific to individual components of the spore coat structure.

\section{Conclusions:}

- Uranium biosorption shows no correlation with gram-positive or gramnegative cell classifications.

- Yeast strains in general appear to biosorb only low amounts of uranium.

- Classification by microbial species can not be used to predict uranium biosorption. Strains that are closely genetically related are expected to exhibit similar uranium biosorption abilities.

- The growth phase of the harvested biomass can affect the potential for uranium biosorption.

- Changes in cell density appear to result in minor differences in uranium uptake.

- To accurately compare uranium biosorption by a specific microbial strain in separate studies, growth conditions should be identical (i.e. culture medium and temperature) and cells must be harvested in same phase of growth.

- B. subtilis spores showed an extremely poor uranium biosorption capacity; spores bound between 11 and $18 \mathrm{mg}$ uranium per gram dry weight of spores.

\section{Acknowledgments}

This work was supported by an post-doctoral LDRD grant to the Glenn T. Seaborg Institute for Transactinium Science at Lawrence Livermore National Laboratory. The author is especially grateful to Dr. Ilham Al Mahammid and Dr. Heino Nitsche for use of laboratory facilities for all uranium chemistry and to Dr. Bob Buchanan for use of laboratory facilities for all microbiological studies. 

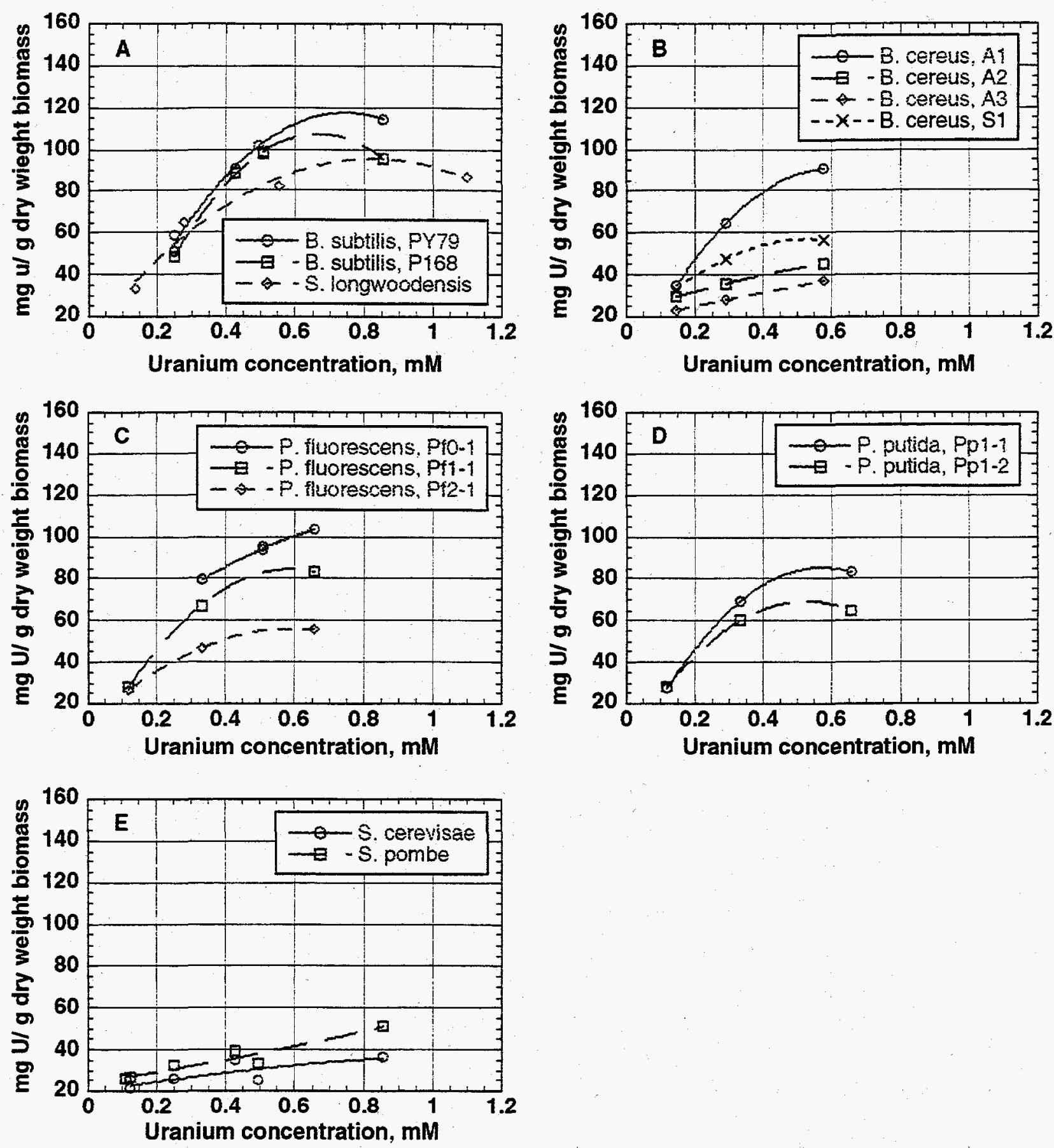

Figure 1 


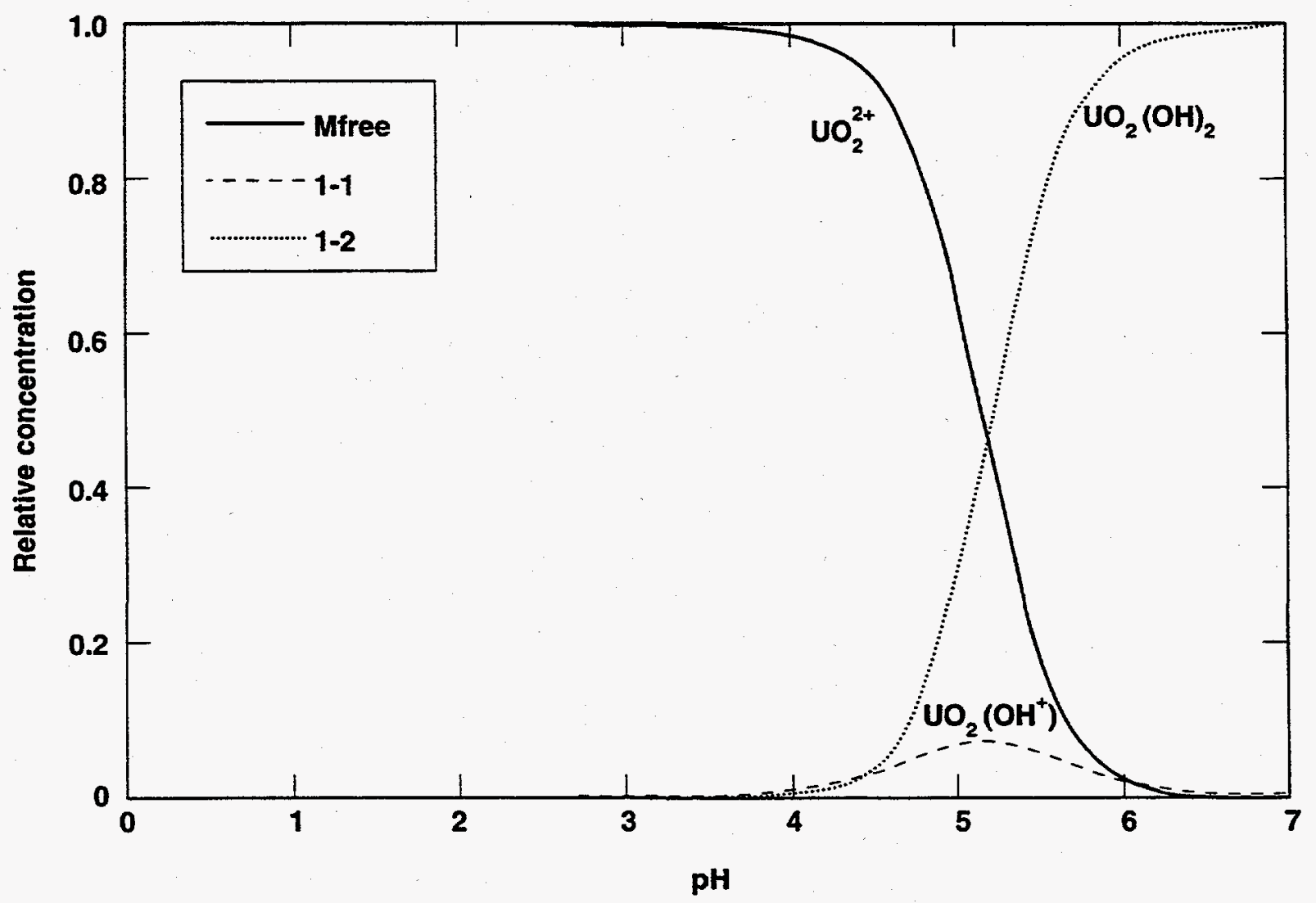

Figure 2 

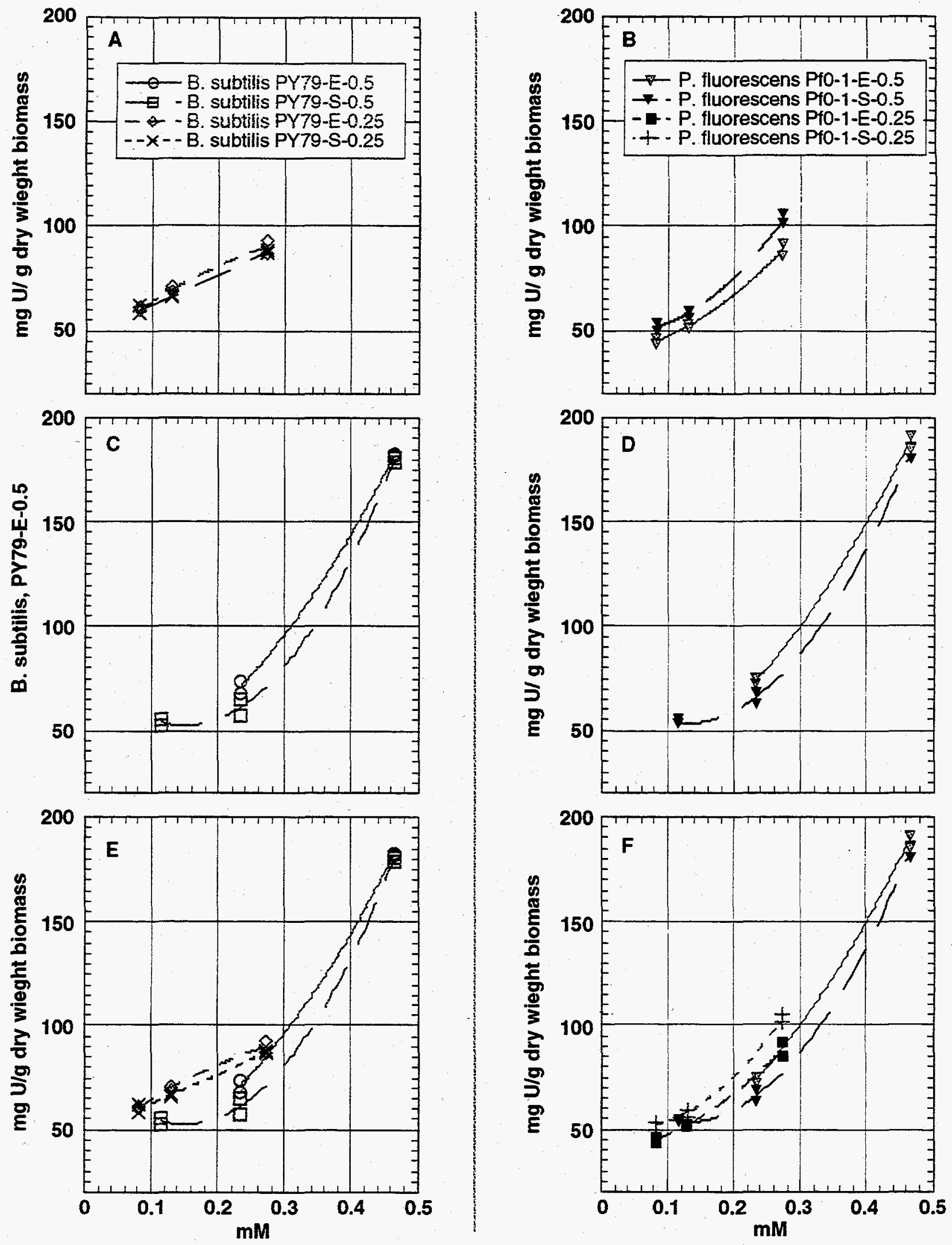

Figure 3 


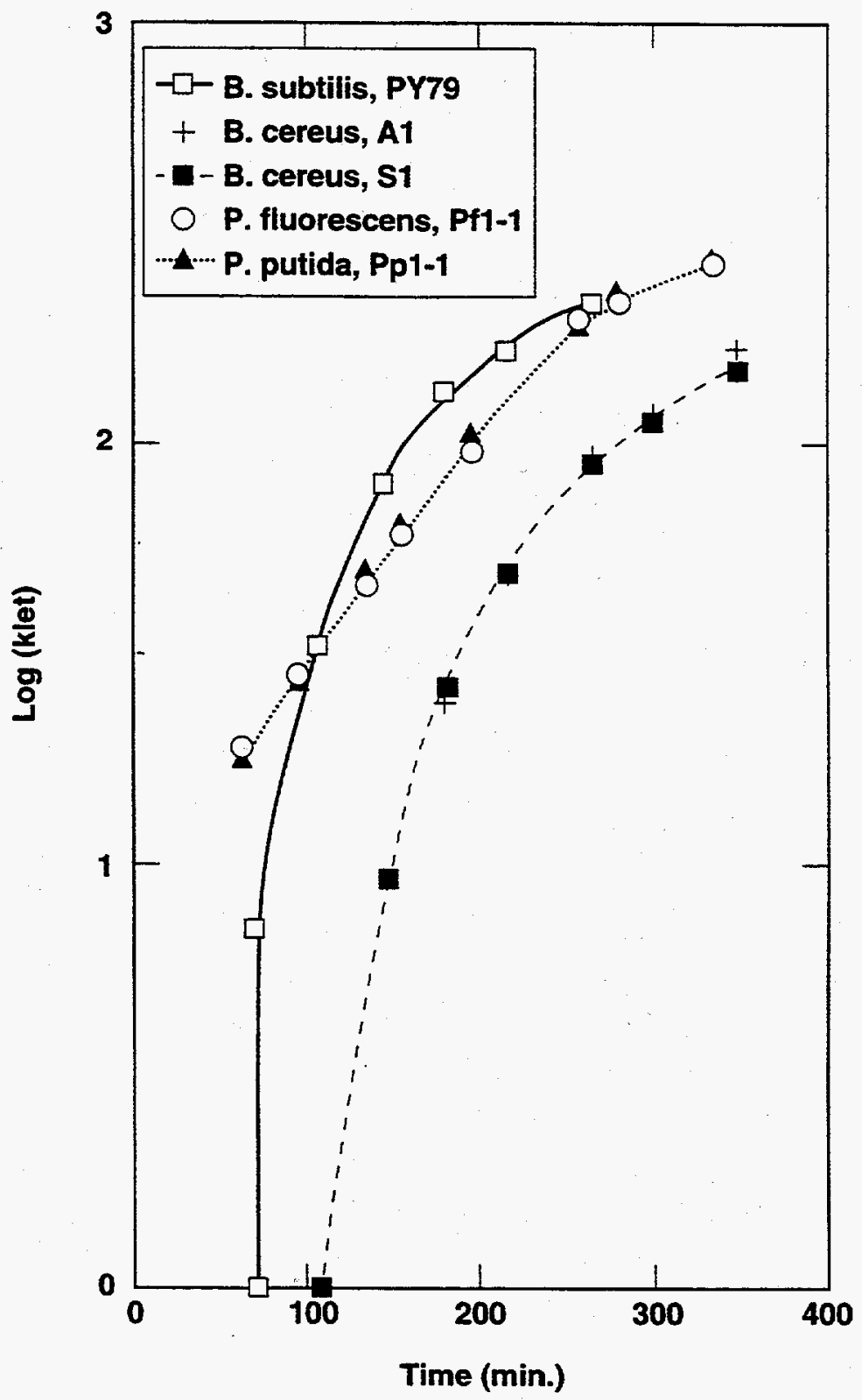

Figure 4. Bacterial growth 

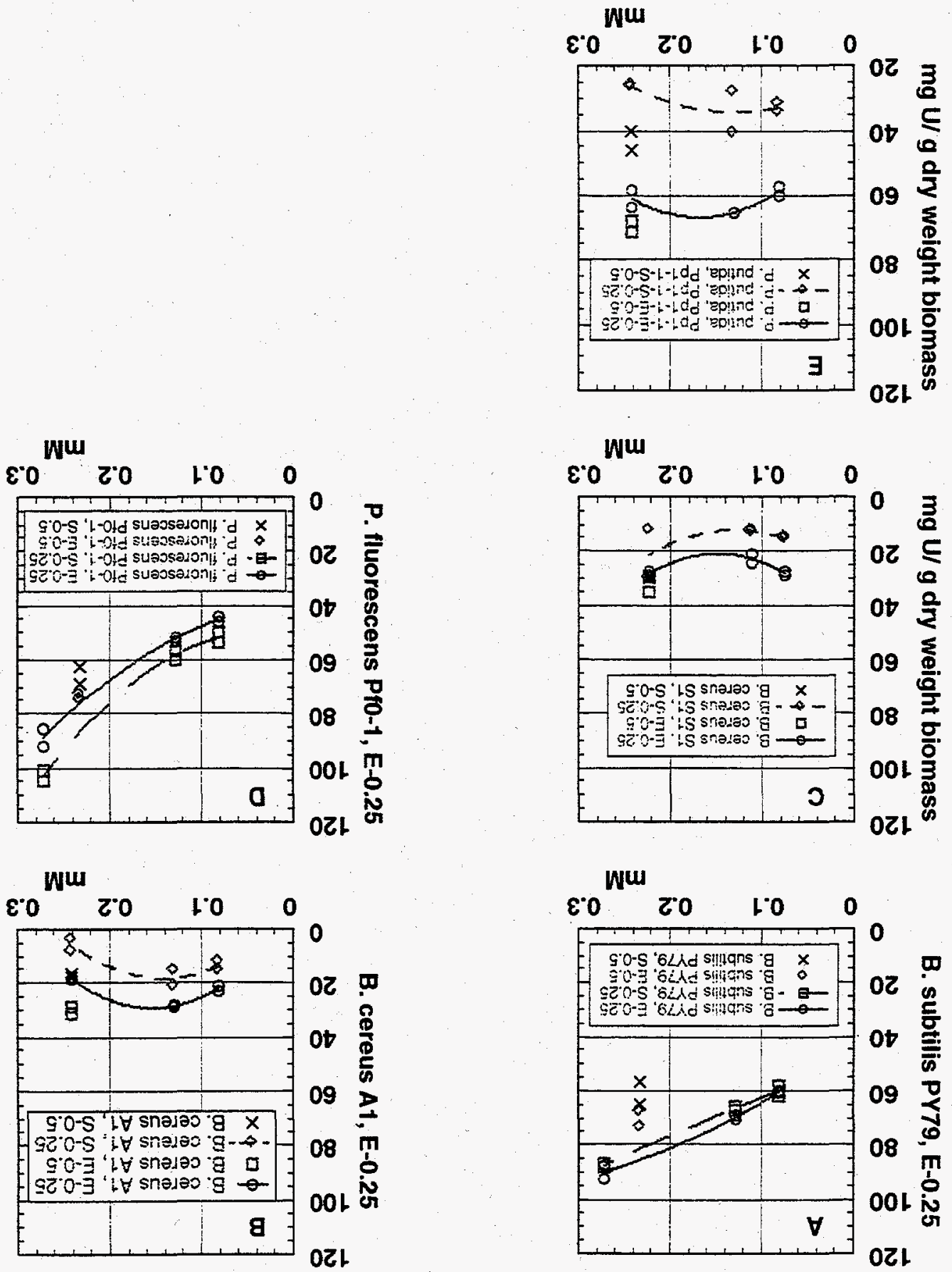
TABLE 1. Microbial strain list.

Microorganism gram stain classification

Bacillus subtilis, PY79, a

Bacillus subtilis, P168,

Bacillus cereus, $6 \mathrm{A1}, \mathrm{a}$

Bacillus cereus, $6 \mathrm{~A} 2{ }^{a}$

Bacillus cereus, $6 \mathrm{~A} 3{ }^{\mathrm{a}}$

Bacillus cereus, $6 \mathrm{~S} 1$, $^{\mathrm{a}}$

Streptomyces longwoodensis, 29251, b

Pseudomonas fluorescens, $\mathrm{Pf} 0-1, \mathrm{~d}$

Pseudomonas fluorescens, Pf1-1, d

Pseudomonas fluorescens, Pf1-2,

Pseudomonas putida, P1-1, d

Pseudomonas putida, P2-1, d

Saccharomyces cerevisiae, FY2, C

Schizosaccharomyces pombe, FWP9, $c$

$+$

$+$

$+$

$+$

$+$

$+$

$+$

+
+
+
+
+
+

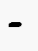

$-d$

-

$-$

NA

NA

a Available from the Bacillus Genetic Stock Center, FAX: (614) 292-3206, INTERNET: dzeigler@magnus.acs.ohio-state.edu.

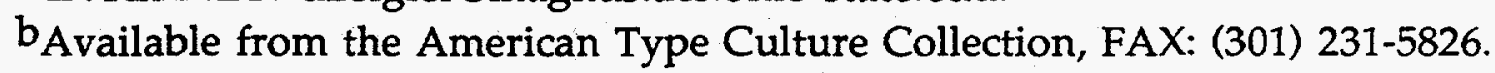

c (Hoffman and Winston, 1984)

$\mathrm{d}$ (Compeau et al., 1988)

NA, not applicable 
TABLE 2. mg Uranium Biosorbed by B. subtilise PY79 spores.

B. subtilis PY79

a
$W$ T
gerE36
$\cot E$
$\cot A$
$\cot B$
$\cot C$
$\cot D$

$\begin{array}{lc} & \text { uranium } \\ 0.2 \mathrm{mM} & \text { concentration } \\ 18 & 0.5 \mathrm{mM} \\ 33 & 11 \\ 19 & 31 \\ 17 & 2 \\ 13 & 9 \\ 1 & 8 \\ \text { ND } & 9 \\ & 4\end{array}$

aStrains available from the Bacillus Genetic Stock Center, FAX: (614) 292-3206, INTERNET: dzeigler@magnus.acs.ohio-state.edu.

ND, below detection 


\section{References:}

Beveridge, T.J., and W.S. Fyfe, 1985. Metal fixation by bacterial cell walls. Can. J. Earth Sci. 22:1893-1898.

Brierley, J.. 1988. United States Patent \# 4,789,481 - Metal Recovery. 1988.

Compeau G; Al-Achi BJ; Platsouka E; Levy SB. Survival of rifampin-resistant mutants of Pseudomonas fluorescens and Pseudomonas putida in soil systems. Applied and Environmental Microbiology, 1988 Oct, 54 (10):2432-8.

Crist, RH, Oberholzer K., Schwartz, D., Marzoff, J., Ryder, D., (1988). Interactions of metals and protons with algae. Environ. Sci. Technol. 22(7):755-760.

Faison, B.D., C.A. Cancel, S.N. Lewis, and H.I. Adler, 1990. Binding of Dissolved Strontium by Micrococcus luteus. Appl. Environ. Microbiol., Dec. 1990, p.3649-3656.

Gadd, G.M., and C. White, 1989. Removal of Thorium from Simulated Acid Process Streams by Fungal Biomass. Biotechnology and Bioengineering, Vol 33, 592-579 (1989).

Hoffman CS; Winston F. A transcriptionally regulated expression vector for the fission yeast Schizosaccharomyces pombe. Gene, 1989 Dec 14, 84(2): 473-9.

Lundgren, D.G., Malouf E.E., (1983). Microbial extraction and concentration of metals. In: Advances in biotechnological processes. Allan R. Liss Inc., New York.

Macaskie, L.E., and A.C.R. Dean. 1989. Microbial metabolism, desolubilization and deposition of heavy metals: metal uptake by immobilized cells and application to the detoxification of liquid wastes. Adv. Biotechnol. Processes 12:159-202.

Mullen, M.D., D.C. Wolf, F.G. Ferris, T.J. Beveridge, C.A. Flemming, and G.W. Bailey, 1989. Bacterial Sorption of Heavy Metals. Appl. Environ. Microbiol. Dec. 1989, p. 3143-3149.

Rusin, P.A., L. Quintana, J.R. Brainard, B.A. Strietelmeier, C.C. Tait, S.A. Ekberg, P.D. Palmer, T.W. Newton, and D.L. Clark. 1994. Environ. Sci. Technol. 1994, 28, 1686-1690. 
Strandberg, G.W., S.E. Shumate II, and J.R. Parrott, Jr., 1981. Microbial cells as biosorbents for heavy metals: accumulation of uranium by Saccharomyces cerevisiae and Pseudomonas aeruginosa. Appl. Environ. Microbiol. 41:237245.

Tobin, J.M., Cooper D.G. and Neufeld, R.J., 1984. Uptake of metal ions by Rhizopus arrhizus biomass. Appl. Environ. Microbiol. 47 821-4.

Treen-Sears, M., Martin, W.M. and Volesky, B. (1984). Propagation of Rhizopus javanicus biosorbent. Appl. Environ. Microbiol. 48, 137-141.

Volesky, B. 1994. Advances in biosorption of metals: Selection of biomass types. FEMS Microbiology Reviews 14 (1994) 291-302.

Wong, P.K., K.C. Lam, and C.M. So, 1993. Removal and recovery of $\mathrm{Cu}(\mathrm{II})$ from industrial effluent by immobilized cells of Pseudomonas putida II-11. Appl. Microbiol Biotechnol (1993) 39:127-131. 